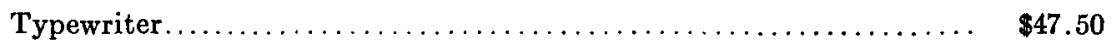

Miscellaneous....................................

$\$ 3,921.16$

Balance on hand $\ldots \ldots \ldots \ldots \ldots \ldots \ldots \ldots \ldots \ldots \ldots \ldots \ldots, \quad 429.27$

$\$ 4,350.43$

There are at present 1462 members of the Association of which 47 are life members fully paid.

\title{
ABSTRACT OF FINAL REPORT OF COMMITTEE ON INSTRUCTION IN POLITICAL SCIENCE
}

The Committee on Instruction appointed to investigate and report on the teaching of Government in schools and colleges presented its final report to the Political Ecience Association at the annual session in Washington. An outline of the contents of the report along with the important recommendations contained therein is presented herewith:

\section{PART I}

I. Stages in the advancement of civic instruction.

II. Efforts to improve the teaching of civics by such organizations as:

(a) National Education Association.

(b) American Historical Association.

(c) National Municipal League.

(d) American Political Science Association.

III. The purpose of courses of instruction in civic affairs.

IV. Methods, material, and devices.

\section{Part II}

I. Suggestive material for courses of study in

(a) Elementary schools.

(b) Junior high schools.

(c) Advanced civics in senior high schools.

(d) Select bibliographies for teachers.

\section{PART III}

I. Report of secondary school instruction by Committee of Seven and Bureau of Education.

II. Reports of state committees on the teaching of civics in separate States.

III. Preparation of teachers-normal schools, colleges, and universities.

IV. Report on the teaching of political science in colleges and universities.

V. Appendix with suggestive programs and successful methods for the teach ing of civics in the public schools. 


\section{A. Recommendations for College Instruction}

I. Establishment of a separate department of Political Science.

II. Elementary course in American government with explanatory material and suggestive comparisons from foreign governments.

III. Special provisions for training of teachers of civics as well as for school administrators.

IV. More emphasis to be given to administrative methods and the enforcement of the law.

V. Preparation of reports and surveys on actual political conditions.

VI. Establishment of reference libraries and research laboratories for study and for the purpose of rendering aid to government officials and interested citizens.

VII. Provisions for professional training for certain branches of the public service.

\section{B. Recommendations for Instruction in Secondary Schools}

I. That a year of social science, exclusive of history, be given in the senior high school, of which at least a half year shall be civics or government, and that 4 or 5 hours per week be given to this subject.

II. That pressure be brought to bear on colleges to accept a full year of civics for entrance when the work is effectively taught.

III. Better preparation of teachers. Courses in normal schools, colleges, and universities designed to prepare teachers of government.

IV. More emphasis on local affairs.

V. Better material, collection of a civics library with reference works, government reports and pamphlet literature illustrating all phases of government work.

VI. Instruction to be made more practical. Such devices are particularly recommended as observation of local government departments, surveys of local conditions, and talks to classes by officials and others interested in governmental problems.

VII. Put civic instruction into civic practice by such devices as self government in school, by organizing classes on the model of government departments, by the formation of civic leagues and community clubs.

The suggestive outlines of courses of study which the committee has prepared are intended to offer material and methods of presentation for some incidental instruction in the elementary school and a full year course for 8th grade or the first year in junior high school, and at least a half year of government for the senior high school. The complete report with these suggestive courses will probably be published and be made available to the members of the Association and others interested. 